\title{
Fotogrammetrie jako optimální technika pro 3D digitalizaci v muzejních institucích
}

Jiři Frank, Josef Kortan, Miroslav Kukrál, Vojtěch Leischner, Lukáš Menšik, Paul Safko, David Sedláček, Eleonóra Stanková

\section{Photogrammetry as an Optimal Method of 3D Digitization in Museum Institutions}

\begin{abstract}
One of the challenges that museums often face is how to present their ,treasures' in a form that is both comprehensive and relevant to today's audiences. Digital content alone is not enough in this context and $3 D$ content is increasingly gaining importance. One of the most accessible and at the same time most effective $3 D$ digitisation methods is photogrammetry. The result, if procedures are followed correctly, is not only high-quality content with a wide range of uses, but also potential stepping stones for effective business models. This can reduce acquisition costs quite significantly and make $3 D$ digitisation accessible to a wider range of institutions.
\end{abstract}

Keywords: 3D digitisation, photogrammetry, museums, cultural heritage, metaverse, virtual production, 3D print

Motto: „Muzeum není v kreativní oblasti jen poskytovatel obsahu, ale i plnohodnotný partner a uživatel."

\section{Úvod}

Základní důvody, které často vedou muzea k 3D digitalizaci, jsou využití pro vědu a výzkum, ochranu a restaurování či prezentaci $\mathrm{v}$ online prostředí. $\mathrm{V}$ tomto př́ipadě má 3D digitalizace zaručeně své místo, protože odbourává problémy s opotřebením předmětů a díky 3D prohlížení je možné s objekty jakkoliv otáčet, přibližovat si je či poslat kolegovi na druhý konec světa. Méně už je řešena otázka uchování takto vzniklých dat, která jsou často objemnější a ve specifických formátech a souborech, narozdíl od výstupů běžné digitalizace. Kromě zmiňovaných tradičních způsobů mají 3D digitalizáty velký potenciál využití v oblasti 3D tisku, produktovém designu, virtuální a rozšírené realitě, vzdělávání a zejména kreativních průmyslů (obr. č. 1).

Kreativní průmysly jsou v poslední době poměrně často skloňovaným slovním spojením v kontextu s kulturním dědictvím a zažívají i díky rozvoji různých technologií výrazného rozmachu. Co vlastně ale jsou? Jak nám mohou pomoci v rozvíjení nových nápadů a inovací v prostředí muzea? Jsou pro ně současný stav a forma zdigitalizovaného kulturního dědictví, např́iklad sbírkových muzejních předmětů, atraktivní a dostatečné? A jsou navíc pro ně muzea žádoucími a perspektivními partnery?

3D digitalizace se díky zdokonalujícím technologiím a službám stává pro kulturní instituce v České republice čím dál tím více dostupná. Stále se však jedná o poměrně náročný a nákladný proces. Proto je často 3D digitalizace realizována pouze v závislosti na účelových prostředcích tuzemských a zahraničních dotačních programů. Pořízení a zpracování 3D reprezentací památek, budov či muzejních sbírek pak instituce většinou realizují ve spolupráci s různými profesionálními dodavateli. Jen zřídka však zatím instituce sami do patřičného hardwarového a softwarového vybavení, včetně profesionalizace vlastních zaměstnanců, investují. Přitom některé 3D digitalizační procesy již efektivní kombinaci vlastního zapojení a spolupráce s externím subjektem nabízejí. I přes vícero možných způsobů 3D digitalizace se jako nejvíce efektivní v této oblasti ukazuje fotogrammetrie, na kterou se tato studie blíže zaměřuje.

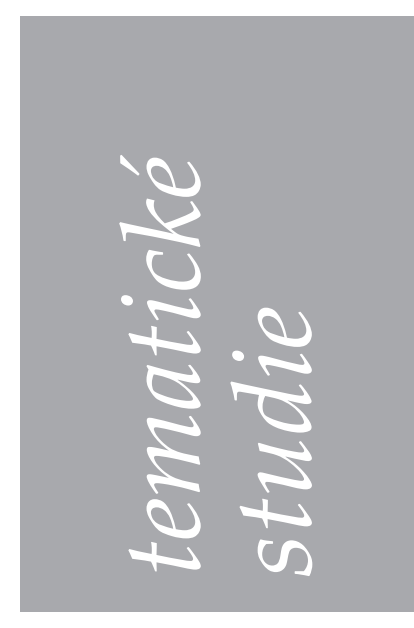

Jiří Frank

jiri.frank@nm.cz

Národní muzeum

Josef Kortan josef.kortan@nm.cz Národní muzeum

Miroslav Kukrál miroslav.kukral@nm.cz Národní muzeum

Vojtěch Leischner info@trackmeifyoucan.com Fakulta elektrotechnická České vysoké učení technické v Praze

Lukáš Menšík lukinec@barbucha.studio Barbucha studio,

Paul Safko studio@paulsafko.com https://www.paulsafko.com,

\section{David Sedláček} david.sedlacek@fel.cvut.cz Fakulta elektrotechnická České vysoké učení technické v Praze

Eleonóra Stanková eleonora.stankova@nm.cz Národní muzeum 


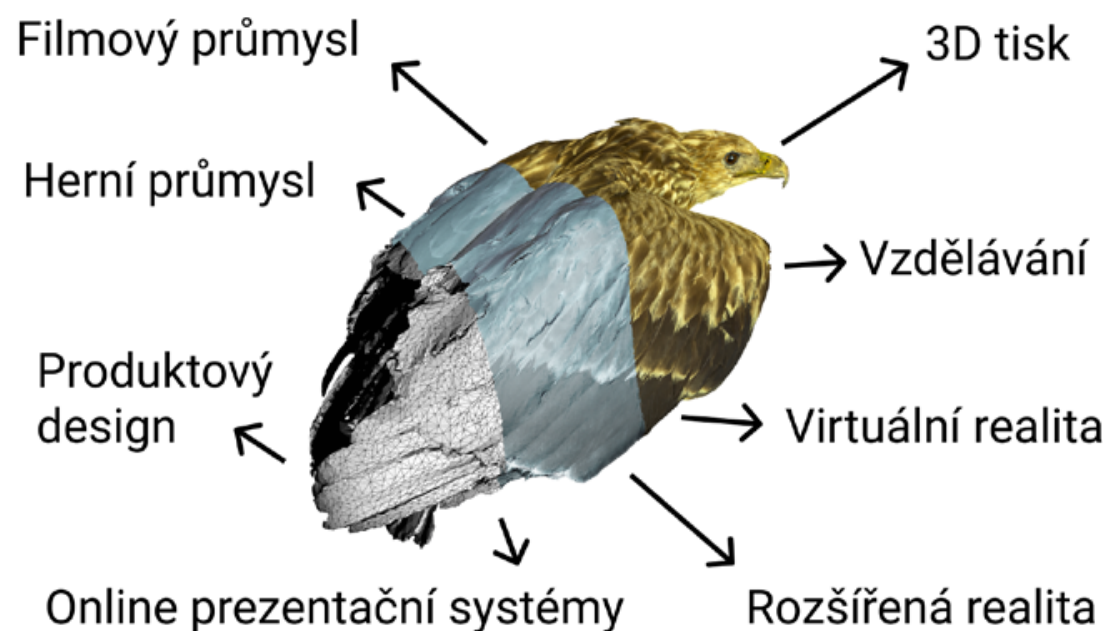

Obr. č. 1 - Rozšírené možnosti využití 3D digitalizovaných sbírkových předmètů oproti tradičnímu prístupu.
1 YOSRA, K. The Manacor Museum $3 D$ printed replicas so that visitors can touch its exhibits. 3D Adept Media [online], July 6, 2018, [cit. 15. 11. 2021]. Dostupné z: https://3dadept. com/the-manacor-museum-3d-printed-replicas-so-that-visitors-can-touch-its-exhibits/) 2 Dostupné z: https://www. blender.org/

3 AYSHA, M. 3D Builder, free 3D modeling software by Microsoft. 3Dnatives [online], August 31, 2020 [cit. 15. 11. 2021]. Dostupné z: https:// www.3dnatives.com/en/3d-builder-microsoft-310820206/\#! 4 Dostupné z: https://makerfaire.czl.
Vzhledem k dosavadní absenci koncepčních materiálů sjednocujících standardizované metodiky $\mathrm{v}$ rámci $3 \mathrm{D}$ digitalizace v ČR i v zahraničí, byly a často ještě porád jsou výše zmíněné postupy a případy spíše experimentálními pokusy, na základě, kterých se jednotlivé instituce „učí za pochodu“. Muzea a galerie se sice mohou navzájem inspirovat a poskytovat si vybudované know-how - většinou však realizace závisí na konkrétních možnostech dané instituce a řeší se izolovaně, bez vedení tolik potřebné dokumentace. Z důvodu nedostatku doporučení na poli 3D digitalizace v českých muzeích vznikla i tato studie a doufejme, že v budoucnu přijdou i tolik potřebné metodiky.

\section{D Tisk, fyzická média a produktový design}

Jednou ze zajímavých a perspektivních oblastí využití 3D digitalizátů sbírkových předmětů otevírá 3D tisk. Díky stálému rozvoji technologií (s výrazným přispěním i české stopy), které jsou již finančně dostupné široké veřejnosti, se otevírají nové možnosti jak na straně uživatelů, tak návštěvníků i institucí. Za přijatelné náklady lze vytvořit repliku exponátu (obr. 2), kterou je díky odolnému materiálu možné využít například pro edukaci či haptickou linku př́mo v expozici či výstavě. ${ }^{1}$ Zároveň je možné digitalizovaný obsah nabídnout návštěvníkům, kteří si jej mohou $\mathrm{v}$ rámci dostupného softwarového vybavení, jako je např́klad open source Blender ${ }^{2}$ či 3D builder vestavný ve Windows $10^{3}$, upravit a doma vytisknout. Mohou si tak odnést část svého zážitku z návštěvy muzea s sebou. Tento přístup navíc může podpořit kreativitu v oblasti lektorských programů, doprovodných akcí, ale i například ve výuce apd. Samozřejmě lze v neposlední řadě zmínit potenciál marketingového využití 3D tisku replik sbírkových předmětů k výstavám či expozicím v muzejních obchodech apd. Zajímavou inspirací využitelnosti 3D tisku v českém prostředí je např́íklad každoročně konaný festival kutilů „Maker faire" ${ }^{\text {, }}$, kde amatérští i profesionální tvůrci vyrábějící vlastní šperky, historické repliky apod. Proč by i toto nemohlo být novým prostředím pro spolupráci mezi veřejností a muzei? Fotogrammetrii jako optimální techniku

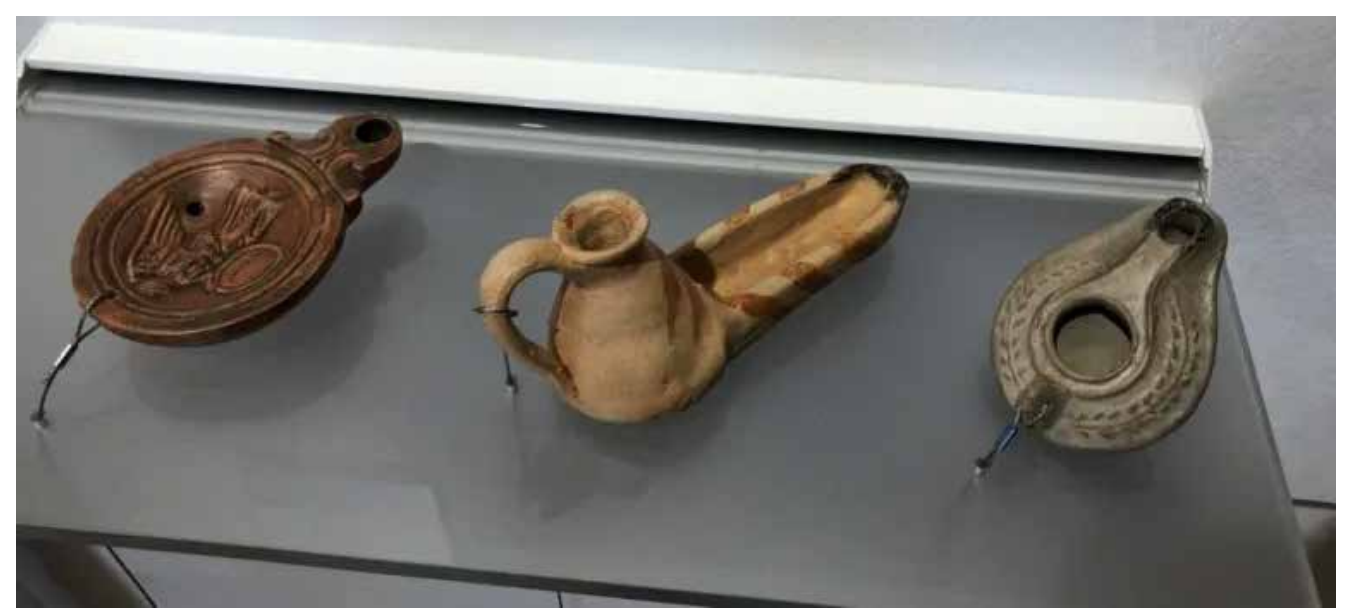

Obr. č. 2 - 3D tisky olejových lamp použitých ve španělském muzeu Manacor, zdroj: https://3dadept.com/the-manacor-museum-3d-printed-replicas-so-that-visitorscan-touch-its-exhibits/ 
pro 3D digitalizaci objektů a jejich následné využití v 3D tisku doporučuje například i společnost Průša Research ${ }^{5}$, která se výrazně na rozvoji technologie v oblasti 3D tisku ve světovém měřítku podílí.

\section{Virtuální a rozšírená realita}

Další z možností využití 3D digitalizovaných sbírkových předmětů je určitě stále se rozvíjející virtuální a rozšířená realita ${ }^{6}$ (Virtual Reality - VR a Augmented Reality - AR). Tyto technologie v poslední době představují nové možnosti prezentace digitalizovaných sbírek interaktivním způsobem jak v kontextu původní doby (např. VR vizualizace hradu před rozsáhlým požárem, nábytku v místnostech apd.) ${ }^{7}$, tak i v lokálním kontextu dané expozice (např. AR vizualizace možné podoby vázy vedle vystavovaného fragmentu) ${ }^{8}$.

Ovšem tyto technologie jako takové nejsou bez potřebného digitálního obsahu ničím. Zatímco vizualizace nedochovaných objektů se dá spíše považovat za kreativní dílo, ${ }^{9}$ tak zobrazení a umožnění interakce s existujícím digitalizovaným obsahem přináší významné benefity i pro seriózní studium a výzkum, a nepovažuje se tedy za pouhý prostředek zvýšení popularizace výstavy. Virtuální realita přináší nový rozměr interakce se sbírkovým předmětem, aniž bychom se museli originálu dotknout. Díky VR je tak např́klad možné si v klidu domova ve velkém detail prohlédnout, což by ani za normálních okolností v muzejní expozici možné nebylo. Přes veškeré benefity je jedinou dosavadní slabinou konceptu VR, že má spíše využití mimo fyzické prostředí muzea. Zážitek často nemohu sdílet s další osobou a ztrácím kontakt s reálným prostředím kolem sebe.

Zde proto tento prostor velmi efektivně vyplňuje rozšířená realita (AR). Ta naopak přináší doplnění informací k vystavovaným exponátům přímo ve výstavě či expozici a tím i obrovský potenciál využití. Můžeme se v kontextu daného exponátu podívat na fotografie objektu $\mathrm{z}$ jiných úhli̊ pohledu, přečíst si doplňkové informace, vizualizovat podobné objekty. ${ }^{10}$
Navíc daný zážitek můžeme díky různým mobilním zařízením sdílet s více lidmi a zároveň neztrácet kontakt s fyzickým prostředím. Díky AR bychom tak mohli v budoucnu efektivně oživovat expozice, které by nám pokaždé mohly přinést jiný zážitek a stát se tak zajímavým interaktivním průvodcem.

\section{Online prezentační systémy}

Prezentačních platforem zobrazujících výsledky 3D digitalizace kulturního dědictví je celá řada, od datových portálů samotných institucí až po mezinárodně rozšířené platformy či sociální sítě. $\mathrm{V}$ rámci českého, evropského a celosvětového prostředí můžeme zmínit alespoň tři př́iklady.

\section{Portál eSbírky}

Portál eSbírky ${ }^{11}$ spravovaný Národním muzeem od roku 2010 zpřístupňuje digitalizované sbírkové předměty více jak 170 kulturních institucí v ČR. Kromě klasických výsledků 2D digitalizace (tj. fotografie a skeny) je možné prostřednictvím portálu publikovat digitalizované sbírky ve 3D (ve formátech .OBJ a 3D PDF). V současnosti je digitální 3D obsah na eSbírkách dostupný pod označením „3D“ a jeho složení je velmi variabilní. 3D objekty, se kterými mohou uživatelé přímo manipulovat, zatím nejsou odlišeny od běžného obsahu a je možné je dohledat jenom díky funkci fulltextového vyhledávání. Aktuálně se v rámci platformy připravuje podpora prezentací 3D virtuálních prohlídek muzejních a galerijních expozic. Obě tato řešení podporují jak přímé ukládání 3D digitálních objektů do administračního systému eSbírky a jejich př́mou prezentaci na platformě, ${ }^{12}$ tak propojování portálu s jiným, „mateřským" zdrojem dat, pomocí URL odka$\mathrm{zu}^{13}$. Záměrem platformy je zefektivnit a zdokonalit prezentaci 3D digitálního kulturního dědictví v návaznosti na vydané domácí i zahraniční doporučení pro tento typ souborů v prríští verzi portálu eSbírky 2.0.
5 ZUZA, Mikolas,

Fotogrammetrie - 3D skenování s použitím fotoaparátu či mobilu, [online], [cit. 15. 11. 2021]. Dostupné z https:// josefprusa.czlfotogrammetrie-3d-skenovani-s-pouzitim-fotoaparatu-ci-mobilul 6 CHAMPION, Erik, Virtual Heritage. London: Ubiquity Press, 2021, p. 153. DOI: https://doi.org/10.5334/bck 7 DEBAILLEUX, Laurent, GEOFFREY, Hismans, DUROISIN, Natacha. Exploring Cultural Heritage Using Virtual Reality. In: M. Ioannides (Ed.), Digital Cultural Heritage. Lecture Notes in Computer Science, Februar 2018, pp. 1-16. 8 GIMENO, Jesús, et al. Combining traditional and indirect augmented reality for indoor crowded environments. A case study on the Casa Batlló museum. Computer \& Graphics, 2017, vol. 69, pp. 92-103.

9 BARRATT, R. P., Speculating the Past: 3D Reconstruction in Archaeology. In: Champion, E. M. (Ed.), Virtual Heritage: A Guide, 2021. London:

Ubiquity Press, pp. 13-23. 10 GIMENO, Jesús, et al. Combining traditional and indirect augmented reality for indoor crowded environments. A case study on the Casa Batlló museum. Computer \& Graphics, 2017, vol. 69, pp. 92-103.

11 Dostupné z: https://esbirky. czl.

12 Např. https://www.esbirky. cz/predmet/3982311.

13 Např. https://www.esbirky.cz/predmet/21069837, https://www.esbirky.czl predmet/22625777, https://www.esbirky.czl predmet/22625801, https://www.esbirky.czl predmet/22625815 
14 Dostupné z: https://www. europeana.eul.

15 Dostupné z: https://pro. europeana.eu/project/3d-content-in-europeana.

16 https://www.europeana.eu/sk/item/2048705/ object_HA_1711

17 Dostupné z: https://sketchfab.com/.

18 Dostupné z: https://sketchfab.com/museums?ref=footer.

19 Dostupné z: https://sketchfab.com/members?segment=organization $\% 2 F m u s e-$

um.

20 Dostupné z: https://sketchfab.com/britishmuseum.

21 Dostupné z: https://creativecommons.orgl .

22 SMITH, Matthew, et al. Using 3D modelling and game engine technologies for interactive exploration of cultural heritage: An evaluation of four game engines in relation to roman archaeological heritage. Digital Applications in Archaeology and Cultural Heritage, September 14, 2019. 23 GIAKALARAS, Marios M. 3D Technologies for Cultural Heritage. Gaming Engines, September 24, 2020, pp. 1-10. 24 SHENG, W., et al. Photorealistic VR space reproductions of historical kyoto sites based on a next-generation $3 D$ game engine., 2015, vol. 1, no.1, pp. 188-204.

\section{Europeana}

Europeana ${ }^{14}$ je prezentační portál, který agreguje digitální obsah kulturních institucí v evropském měřítku již od roku 2008. V lednu 2019 zde byla vytvořena pracovní skupina, která se zaměřila na podporu 3D digitalizovaného kulturního dědictví na platformě Europeana a jeho využití v oblasti vzdělávání, výzkumu a kreativních průmyslů. Výsledkem činnosti této skupiny ${ }^{15}$ je soubor doporučení, jak publikovat výstupy 3D digitalizace $\mathrm{v}$ online prostředí $\mathrm{v}$ kontextu platformy Europeana a jejich uživatelù. Dále doporučení formátů pro 3D média a prohlížečů integrovaných do prostředí platformy a jejich agregátorů. A nakonec samotná adaptace publikačního rámce a jeho úrovní pro 3D digitální objekty na platformě. Portál Europeana prezentuje více než 17000 publikovaných 3D digitálních sbírkových předmětů, přičemž jsou zde využity různé formy jejich zobrazení. Zřejmě nejvyužívanějším způsobem prezentace 3D obsahu na platformě je zobrazování modelů prostřednictvím powerpointových či pdf prezentací, které však nejsou často plně funkční. Další možností prezentace tohoto typu předmětů je, stejně jako $\mathrm{v}$ případě eSbírek, přesměrování na zdrojovou webovou stránku, nebo na jinou publikační platformu pro 3D obsah, např́iklad Sketchfab ${ }^{16}$.

\section{Sketchfab}

Jednou z nejrozšířenějších komerčních platforem pro publikaci 3D digitálního obsahu ve světovém měřítku je Sketchfab ${ }^{17}$. Kromě samotné publikace/zveřejnění poskytuje možnost sdílení, prohledávání, nákupu a prodeje 3D, VR a AR obsahu. Sketchfab má integrovaný prohlížeč založený na technologiích WebGL a WebXR, díky kterým je možné prohlížet 3D modely v jakémkoli počítačovém či mobilním prohlížeči, nebo skrze zařízení pro zobrazení virtuální reality. Sketchfab má navíc přímo vlastní sekci zaměřenou na 3D cultural heritage ${ }^{18}$, kde jsou již publikovány tisíce sbírkových předmětů z muzeí a kulturních institucí po celém světě ${ }^{19}$. Příkladem může být například
British museum se svými 273 publikovanými 3D objekty. ${ }^{20} \mathrm{U}$ každého předmětu jsou publikovány kromě metadat popisných i metadata technická. Díky tomu lze i ověřit, že drtivá většina digitalizovaných předmětů byla provedena právě technikou fotogrammetrie. Častým a důležitým údajem je dále odkaz na stránky či datový portál instituce, kde se o objektech a jejich kontextu mohou zájemci dozvědět další důležité informace. Lze samozřejmě odkazovat i na platformy jako eSbírky či Europeana. V neposlední řadě je důležité uvedení licence určující možnosti využití objektu, například formou licencí Creative Commons ${ }^{21}$.

\section{Herní průmysl a vzdělání}

Zmiňujeme-li kreativní průmysly, tak určitě nelze opomenout širokou oblast herního průmyslu, kde má propojení zábavy a vzdělávání v kombinaci s kulturním dědictvím, a nejen 3D digitalizovaným obsahem obrovský potenciál. Právě autentičnost sbírkových předmětů a jejich kontext v historii, událostech, v příbězích v kombinaci s důležitými informacemi, které obsahují či představují, jsou lákavým a unikátním obsahem. Díky široké škále platforem od mobilních a dotykových zařízení, přes PC a konzole až po VR a AR a zároveň obrovské celosvětové komunitě napříč věkovými kategoriemi, je herní průmysl pro muzea, kulturní instituce a vůbec kulturní dědictví velmi důležitým odvětvím. At’ již mluvíme o gamifikaci jako takové, herních aplikacích využitých ve výstavách a expozicích či o plných videohrách.

Herní průmysl je zároveň jedním z odvětví, které vytváří pro oblast 3D digitalizace specifické požadavky jak na proces, tak i kvalitu, a posouvá je dalším směrem. Navíc tento vývoj přináší herní prostředí a techniky přenositelné a využitelné právě pro 3D digitalizaci a vizualizaci v oblasti kulturního sektoru. ${ }^{22,23}$ Konkrétně se technologie určené původně pro vývoj her uplatňují například při zpřístupnění digitálního modelu historických center měst pro virtuální prohlídku v reálném čase ${ }^{24}$. 
Propojení vzdělávání, kulturního dědictví a herního průmyslu tak znamená zcela přirozený vývoj. Pro ukázku lze uvést minimálně dva velmi úspěšné př́klady. Jedním z nich je mezinárodně úspěšná RPG hra ,Kingdom Come: Deliverance“25 od české společnosti Warhorse Studio ${ }^{26}$, která poskytuje velmi detailní pohled do prostředí a doby Českého království v období 15. století (1403). Díky velkému důrazu na detail, autentičnost doby a zasazení reálných scén a prostředí je hra využívána ve výuce například na Masarykově univerzitě v Brně. ${ }^{27}$ Jako druhý př́klad lze určitě uvést sérii her "Assasin Creed" od francouzského vydavatele Ubisoft ${ }^{28}$, který se své hry snaží, i když s fiktivními příběhy, zanést do kontextu historických událostí a lokací. V rámci posledních titulů jako např́íklad "Origins", ,,Oddysey“ či „Valhalla“ byl spuštěn speciální výukový mód „Discovery Tour “29 (obr. č. 3). V rámci tohoto módu se může hráč/uživatel naučit více o reálných faktech historie starodávného Řecka, Egypta či doby Vikingů. Kromě reálných míst přenesených do hry včetně architektury, soch apd. se ve hře objevují reálné 3D zdigitalizováné sbírkové předměty (obr. č. 4). Díky tomu se i hra objevuje jako doprovodný výukový materiál v hodinách dějepisu v některých

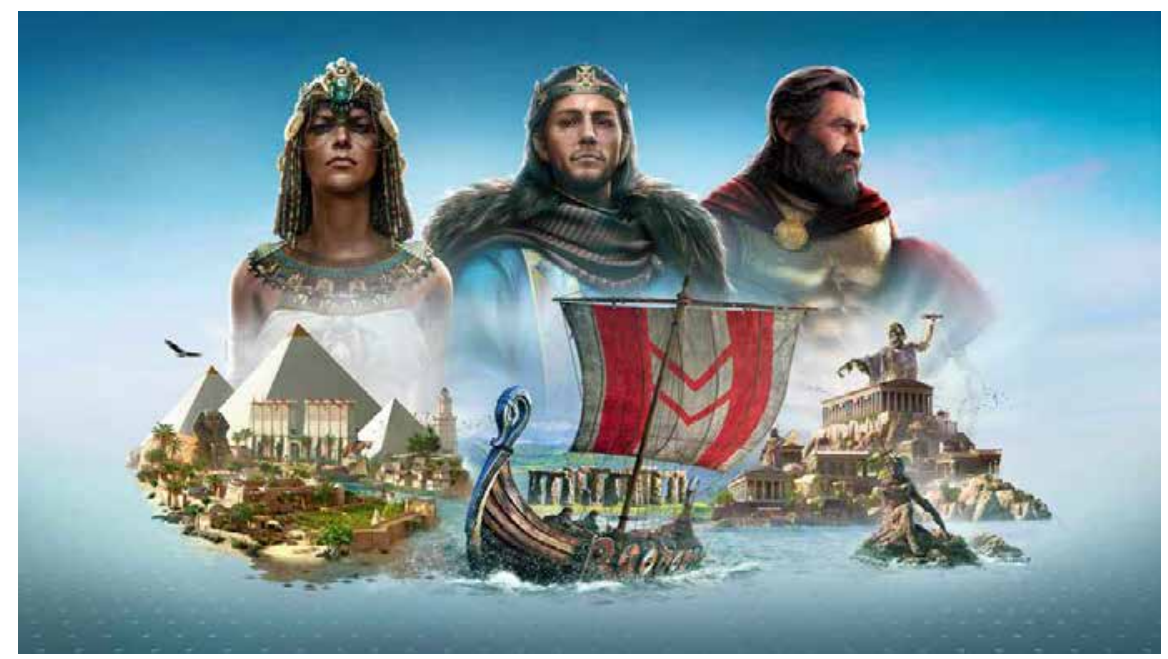

školách po celém světě. Jako zajímavost lze zmínit, že díky podkladiom a digitalizaci reálných lokací ve hře „Assasin Creed: Unity" se Ubisoft zapojil do pomoci rekonstruovat vyhořelou katedrálu Notre-Dame ${ }^{30}$.

\section{Filmový průmysl a počítačová animace}

V poslední době zažívá fotogrammetrie také velké využití v oblasti filmového průmyslu, kde mnoho let panoval klasický způsob vytváření 3D modelů pomocí modelovacích nástrojů (např. Maya, Blender, 3DsMax). To dává další prostor pro využití digitalizovaného 3D obsahu kulturního dědictví, aniž by bylo vystaveno riziku poškození nebo aby bylo nutné vytvářet nákladné repliky. Filmový průmysl stále více propojuje a implementuje technologie a metody, které byly dříve součástí

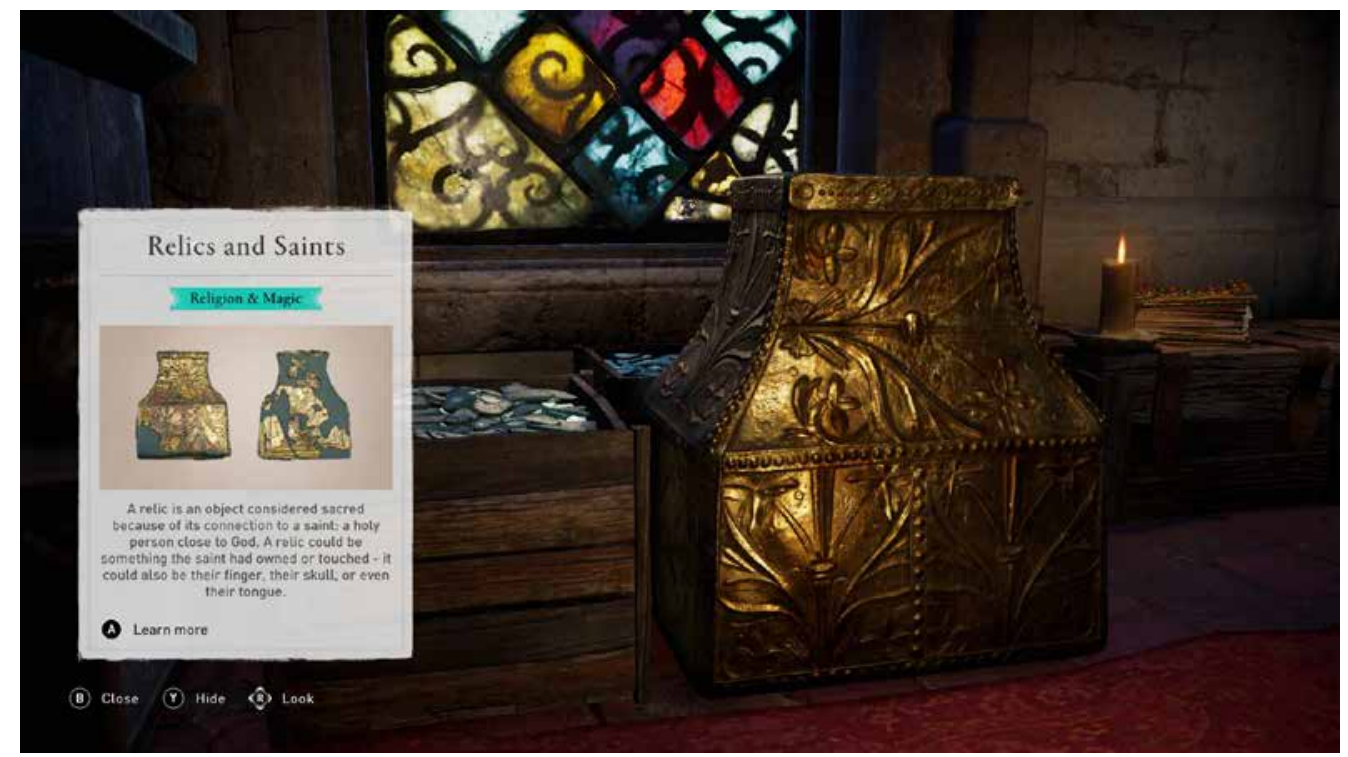

Obr. č. 4 - Ubisoft Discovery tour digitalizovaný předmět ve hře, zdroj: Ubisoft tour, zdroj: Ubisoft

25 Dostupné z: https://www. 26 Dostupné z: https://warhorsestudios.czl.

27 kar. V Brně se učí historie podle videohry Kingdom Come. Podívejte se, jak přednášky vypadají. ČT24 [online], 20. 11. 2018 [cit. 15. 11. 2021]. Dostupné $z$ : https://ct24.ceskatelevize.czl veda/2656931-v-brne-se-uci-historie-podle-videohry-kingdom-come-podivejte-se-jak-prednasky-vypadaji

28 Dostupné z: https://www. ubisoft.com/.

29 Dostupné z: https://www. ubisoft.com/en-gb/gamel 30 REA, Naomi. Can

"Assassin's Creed" Help Rebuild Notre Dame? How Restoring the Cathedral will Rely on Both New Tech and Ancient Knowhow. Artnet [online], April 18, 2019 [cit. 15. 11. 2021]. Dostupné z: https://news.artnet.com/market/how-technologies-old-an$d$-new-will-be-needed-to-rebuild-notre-dame-1520689.
Obr. č. 3 - Ubisoft Discovery kingdomcomerpg.com/cs. assassins-creed/discovery-tour. 
31 Dostupné z: https://www. ilm.com/.

32 BARRATT, R. P., Speculating the Past: $3 D$ Reconstruction in

Archaeology. In: Champion,

E. M. (Ed.), Virtual Heritage:

A Guide, 2021. London:

Ubiquity Press, pp. 13-23.

33 SCHÖNBERGER, Johannes

L., FRAHM, Jan-Michael,

Structure-from-Motion

Revisited, 2016 IEEE

Conference on Computer

Vision and Pattern Recognition

(CVPR), 2016, pp. 4104-4113,

doi: https://doi.org/10.1109/

CVPR.2016.445.

34 MONTUSIEWICZ, Jerzy, et al, Structured-light 3D scanning of exhibited historical clothing - a first-e-

ver methodical trial and its results. Heritage Science,

2021, vol. 9, no. 74, pp.

1-20. https://doi.org/10.1186/ s40494-021-00544-x

35 EBRAHIM, Mostafa, AbdelBary, 3D Laser Scanner's Techniques Overview. International Journal of

Science and Research, October 2015, vol. 4, no. 10, pp. 323-331.

36 SKARLATOS, D., KIPARISSI, S., Comparison of laser scanning, photogrammetry and SFM-MVS pipeline applied in structures and artificial surfaces, ISPRS Ann. Photogramm.

Remote Sens. Spatial Inf. Sci, 2012, I-3, pp. 299-304. pouze herní oblasti. Vzrůstající kvalita algoritmů a výkonu grafických karet, díky nimž dosahují některé současné videohry hyperrealistického vzhledu, mají vysoký potenciál využití pro filmové natáčení. Tomuto způsobu natáčení se říká „virtuální produkce“ či anglicky xR (eXtendet Reality) a byla použita např́klad při natáčení seriálu „The Mandalorian“. Zde v podstatě celé virtuální prostředí krajiny bylo vytvořené pomocí detailních fotogrammetrických modelů realizovaných společností Industrial Light \& Magic, ${ }^{31}$ která vytvořila digitální kopie prostředí např́iklad z Tunisu či Irska.

\section{D digitalizační techniky}

V současné době existuje široké množství způsobů, jak vytvořit 3D digitální předmět na základě jeho reálné podoby. $V$ základním dělení je můžeme rozdělit na dva přístupy.

První př́istup je založen na tradičních metodách vytvárení 3D obsahu, jako je vytváření modelů dle technických výkresů, fotografií nebo náčrtků. Zde se většinou používají modelovací techniky a nástroje určené pro umělce (např. programy Blender, Maya, 3ds Max, Cinema4D, apd.), tak i pro tvorbu technické dokumentace (programy označované jako CAD, Inventor, Catia, Fusion apd.). Zde se předpokládá významný podíl ruční práce umělce/technika, kdy věrnost původní podobě objektu je nejistá. Aktuálně se tyto techniky používají spíše pro rekonstrukci objektů, které nebyly plně zachovány nebo nejsou vhodné pro druhý prístup. ${ }^{32}$

Druhým přístupem je snímání na základě reality, podobně jako se tomu děje již dlouhou dobu $v$ př́padě plošných objektů (např. záznam tisku pomocí skeneru, nebo obrazu pomocí fotoaparátu). Hlavním rozdílem oproti plošným objektům je u 3D digitalizace nutnost pořízení zázna$\mathrm{mu}$ objektu $\mathrm{z}$ více směrư ${ }^{33}$. Benefitem tohoto způsobu digitalizace oproti prvnímu př́stupu je časová úspora a mnohonásobně vyšší věrnost předloze. Techniky $3 \mathrm{D}$ digitalizace jsou škálovatelné dle velikosti objektu od jednotek mikrometru až po kilometrové vzdálenosti.

Primárně rozeznáváme tři základní př́ístupy pro digitalizaci prostorových objektů. Dělení je založeno na použitém technickém vybavení, ale jednotlivé př́istupy se vzájemně doplňují a mají mnohé znaky společné. Prvním je laserové skenování založené na měření doby, za jakou se odrazí světelný impuls od měřeného objektu (LiDAR). Druhým je laserové skenování založené na triangulačním principu, někdy označované jako tzv. strukturované světlo $^{34}$. Třetím principem je fotogrammetrie, tj. technika založená na pořízení mnoha fotografií snímaného objektu. V následujících odstavcích popíseme základní principy a vhodnost daných metod.

Tzv. laserové skenování je nejednoznačný pojem používaný (a zaměňovaný) pro první i druhý př́stup popsaný $\mathrm{v}$ předešlém odstavci. Oba dva totiž používají laserový paprsek (nebo skupinu paprsků) pro měření vzdálenosti $s$ tím, že se liší princip výpočtu dané vzdálenosti. ${ }^{35}$ Jak jsme se již zmínili, $v$ př́padě LiDARu dochází $k$ výpočtu vzdálenosti od měřeného objektu pomocí měření doby mezi vysláním impulsu světla (nebo i zvuku) a jeho opětovnou detekcí ( $\mathrm{zv}$. ToF princip - Time of Flight). LiDARy většinou měří bodově, jednotky bodů v témže okamžiku a mechanicky se rozšiřují pro měření $\mathrm{v}$ dalších bodech. Vzhledem k použité technologii se hodí pro záznam na větší vzdálenosti jako jsou rozsáhlé předměty, budovy, krajiny s dostatečným množstvím detailů. ${ }^{36}$ Tento způsob skenování se využívá i ve stavebnictví a např́klad pasportizaci historických objektů či rozsáhlých archeologických nalezištích. Výstupem je obecně mračno bodů s poměrně řídkou hustotou (obr. č. 5). Existují metody pro převod tohoto mračna na tzv. mesh, tj. 3D objekt reprezentovaný sítí sousedících mnohoúhelníků (polygonů) vytvářejících výsledný vizuální dojem povrchu "plného" objemu reálného předmětu.

Zatímco u LiDARu se světelný impuls vysílá ze stejného místa, jako je následně přijímán, u triangulačního principu je naopak potřeba měřitelná vzdálenost mezi 
zdrojem světelného paprsku a jeho detektorem. Zdroj světla, detektor a místo odrazu paprsku tak tvoří trojúhelník, z nějž jsme schopni vypočítat vzdálenost od měřeného objektu. ${ }^{37}$ Světelný zdroj často vytváří mnoho paprsků nebo proužků světla v blízkém infračerveném spektru. Proto je tato technologie náchylná na okolní světlo (sluneční záření je vysoce rušivé) a hodí se pro skenování drobných až středně velkých objektů. Skenery založené na tomto principu se vyrábí jak stacionární, tak ruční. Výstupem je mračno bodů (nebo hloubková mapa) s mnohem vyšší hustotou než z LiDARu.

Zatímco předešlé metody jsou založené na specifickém záznamovém zařízení, pro fotogrammetrii stačí kvalitní digitální fotoaparát a vhodné programové vybavení. Fotogrammetrie je tak mnohem finančně dostupnější pro širší použitíi ${ }^{38}$. Základem této metody je pořizení mnoha fotografií z různých úhlů pohledu na objekt a následné zpracování počítačovými programy, které jsou k dispozici jak komerční, tak i volně dostupné. ${ }^{39}$ Postupy používané pro digitalizaci fotogrammetrií jsou popsány v následujících sekcích. Významnou výhodou fotogrammetrie je kromě detailní geometrie objektu také záznam barvy povrchu předmětu ve vysokém rozlišení

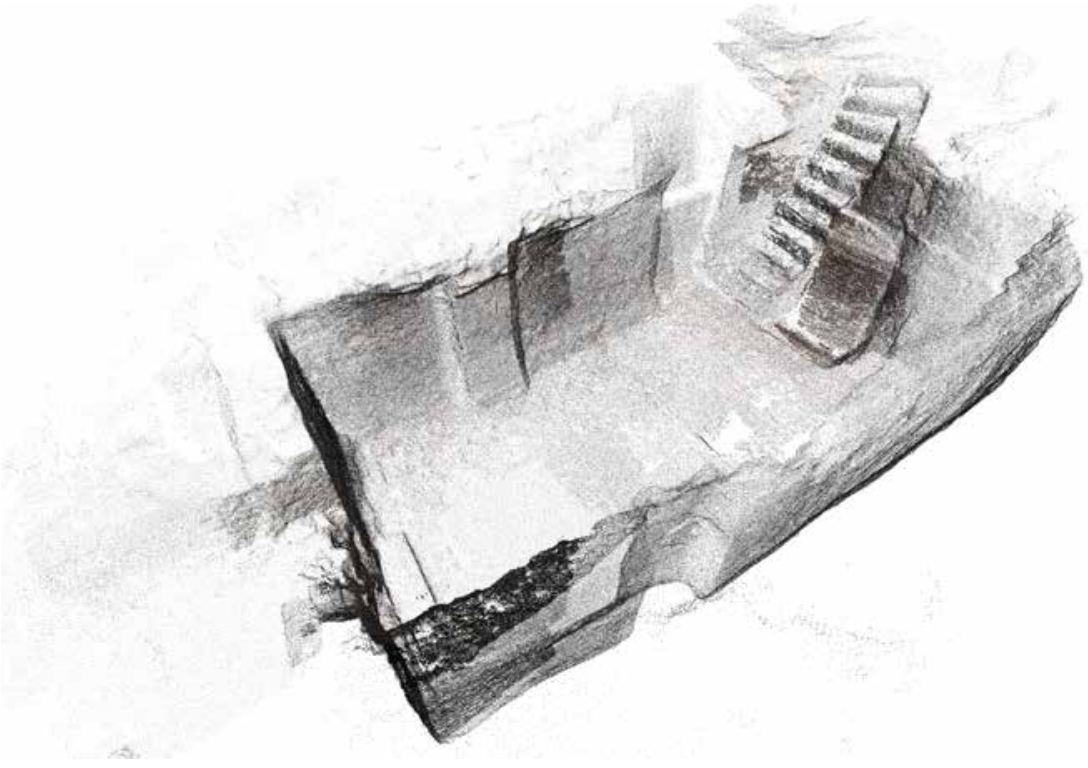

fotoaparátem ve viditelné části světelného spektra, model má tedy vysokou vizuální kvalitu přirozenou lidskému vnímaní skutečného předmětu. Žádná jiná metoda (skenování pomocí principu strukturovaného světla, laserové 3D skenery všech kategorií atd.) nedosahuje srovnatelných vizuálních kvalit a přirozeného podání barev výsledného 3D modelu, zejména $z$ důvodu že barvotvorný proces u těchto metod vzniká „dodatečně” $\mathrm{k}$ bezbarvému záznamu geometrie skenovaného předmětu a to "doplňkovými" CCD/CMOS moduly a optickými elementy, které se kvalitativně nedají s kvalitními fotoaparáty a fotoobjektivy srovnávat. I ty nejdražší laserové 3D skenery nejvyšší kategorie jsou pro sekundární záznam barvotvorných informací osazeny "fotomoduly"
Obr. č. 5 - Ukázka bodového mračna - pointcloudu pořizeného díky laserovému skenování mistnosti, zdroj: David Sedláček

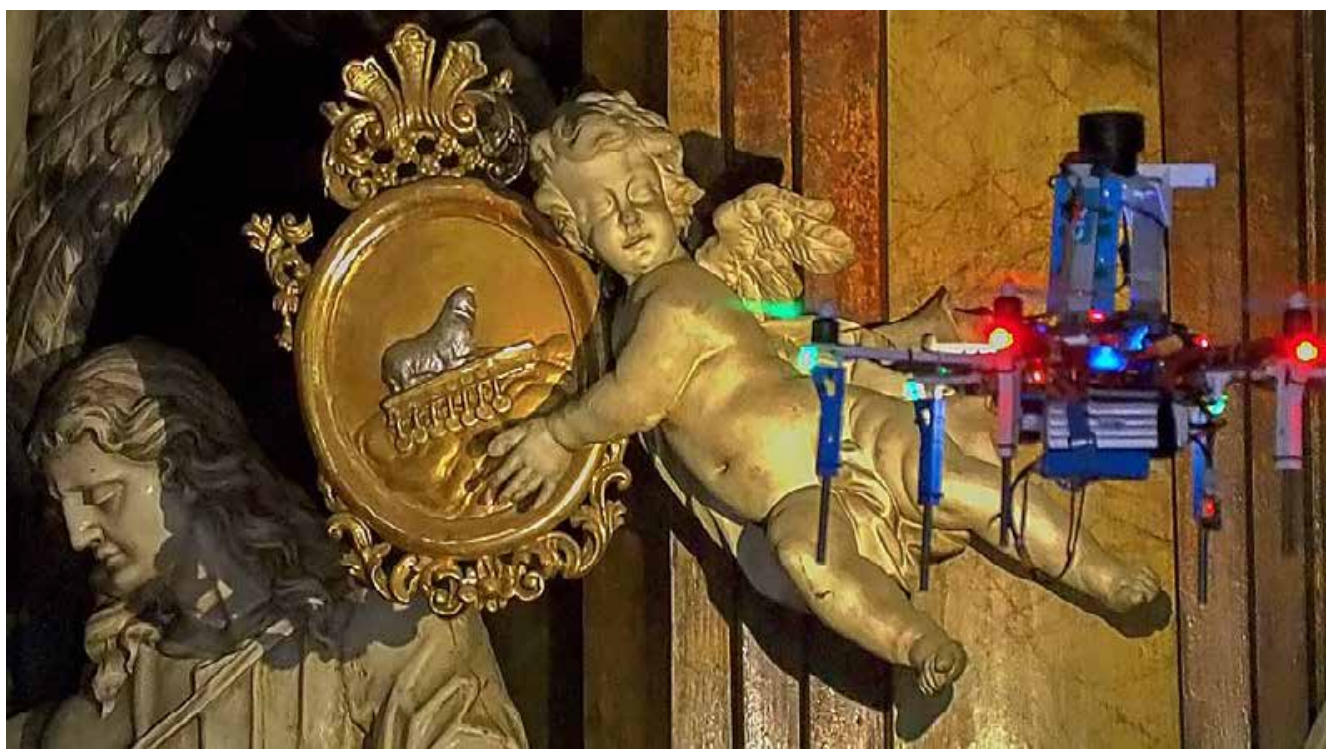

Obr. č. 6 - Skenování technikou fotogrammetrie za pomoci dronu, zdroj: Dronument.cz
37 EBRAHIM, Mostafa, AbdelBary, 3D Laser Scanner's Techniques Overview. International Journal of Science and Research, October 2015, vol. 4, no. 10, pp. 323-331.

38 RAHAMAN, Hafizur and CHAMPION, Erik, To 3D or Not 3D: Choosing a Photogrammetry Workflow for Cultural Heritage Groups, Heritage, 2019, vol. 2, no. 3, pp. 1835-1851.

39 RAHAMAN, Hafizur, CHAMPION, Erik, BEKELE, Mafkereseb. From photo to $3 D$ to mixed reality: A complete workflow for cultural heritage visualisation and experience. Digital Applications in Archaeology and Cultural Heritage, 2019, vol. 13. 40 Dostupné z: https://dronument.czl. 
41 BENTKOWSKA-KAFEL, and LINDSAY, MacDonald. Digital Techniques for Documenting and Preserving Cultural Heritage. New edition ed., Arc Humanities Press, 2018. 369 p. muse.jhu.edulbook/80843. 42 APOLLONIO, Fabrizio, et al, A Photogrammetry-Based Workflow for the Accurate 3D Construction and Visualization of Museums Assets, Remote Sensing, 2021, vol 13, no. 3: 486. https://doi.org/10.3390/ rs13030486

$43 W O O D, J . R .$, et al, Structure from motion photogrammetry endhances paleontological resource documentation, research, preservation and education efforts for national park service areas. In book: Fossil Record 7, Publisher: New Mexico Museum of Natural History and Science, 2021, pp.

513-524

44 MEDINA, Joshua J., et al, $A$ rapid and cost-effective pipeline for digitization of $\mathrm{mu}$ seum specimens with $3 D$ photogrammetry. PLOS ONE, 2020, vol. 15(8), pp. 1-14: e0236417. https://doi.org/10.1371/journal. pone.0236417

45 Dostupné z: https://arxiv. org/abs/1412.1330

46 LINGUA, Andrea, PIUMATTI, Paolo, RINAUDO, Fulvio, Digital photogrammetry: a standard approach to cultural heritage survey.

The International Archives of the Photogrammetry,

Remote Sensing and Spatial Information Sciences, 2003, Vol. 14, Part 5/W12, pp.

210-215

47 RELJIĆ, I. \& DUNDER, Ivan, Application of photogrammetry in 3D scanning of physical objects. TEM Journal, 2019, vol. 8, pp. 94-101. https://doi. org/10.18421/TEM81-13.

48 GRUEN, Armin, Everything moves: The rapid changes in photogrammetry and remote sensing, Geo-spatial Information Science, 2021, vol. $24: 1$, pp. 33

49, DOI: $10.1080 / 10095020$.

2020.1868275 srovnatelnými maximálně s komponenty vestavěnými v dražších mobilních telefonech, nejdou srovnávat s fotoaparáty adekvátní cenové kategorie a vice-versa.

Navíc fotogrammetrie také umožňuje zachytit rozměrné objekty (historické budovy), které by standardním ručním laserovým skenerem nebylo možné zachytit. Reálně je možné si s pomocí dronu vytvořit 3D model kompletní historické památky (obr. 6) nebo archeologického naleziště. Pro archeologická naleziště je případně ideální využití kombinace s laserovým zaměřením či skenováním, kde je nutné dbát na přesnost vzdáleností a měření. Dobrým př́íkladem je projekt Dron \& Monument, ${ }^{40}$ na kterém se podílí zástupci technologické špičky v České republice ve spolupráci s Národním památkovým ústavem.

Bohužel, všechny metody založené na detekci světla mají problém s digitalizací průhledných a vysoce lesklých/zrcadlových objektů. Řešením může být v některých konkrétních případech kombinace polarizačních filtrů, aplikace speciálních inertních matnících sprejů, či jemného inertního prachu, které samozřejmě nepoškozují povrch snímaného předmětu.

\section{Fotogrammetrie a optimální pracovní postup}

V následujících krocích je popsán postup a důležité rady, které je nutné brát na zřetel pro docílení ideálních výsledků z pohledu kvality a využití digitálního 3D modelu snímaného sbírkového předmětu. Postup vychází z dlouholetých ověřených zkušeností v oblasti digitalizace formou fotogrammetrie $\mathrm{v}$ kulturním i soukromém sektoru a z již publikovaných studiín $41,42,44,45,46,47,48$, které obsahují detailnější technologické a technické specifikace.

\section{Výběr, klasifikace, roztřídění} předmětů určených pro digitalizaci Jedná se o př́ipravnou fázi 3D digitalizačního projektu s jedním či více předměty ke skenování. V této fázi je nutná kooperace s kurátory a pracovníky muzea či externími specialisty, kteří budou provádět skenování. Čas věnovaný této fázi přípravy digitalizačního projektu se pozitivně projeví v úspoře času potřebného k samotné digitalizaci. Předměty je vhodné zařadit do skupin vyžadující stejný přístup/postup dle následujících kritérií.

- Rozměry předmětu z hlediska snímání a potřebného technického vybavení, které vytváří nároky na:

- osvětlení

- manipulaci

- prostor kolem předmětu potřebného ke snímání

- transport

- Hmotnost předmětu (z pohledu manipulace $s$ předmětem, nosnosti $360^{\circ}$ točny, transport)

- Povrchové a materiální vlastnosti reflexnost/lesk/odrazivost povrchu, kdy můžeme rozlišit:

- vysoce lesklé

- transparentní

- translucentní

- místa bez detailu (např. černá látka, jednobarevný samet)

- Požadavky na vícenásobné parciální skenování (změna polohy předmětu v průběhu procesu 3D skenování, nutnost otočení apd.)

- Speciální požadavky na fixaci předmětu během 3D skenování

- Časové možnosti dostupnosti / př́stupu ke sbírkového předmětu $\mathrm{k}$ digitalizaci

- Čas potřebný pro restaurátorské úkony potřebné před samotnou digitalizací

\section{Výběr a př́prava prostoru pro 3D skenování}

V této fázi je nutné vymezit dostatečný prostor nutný pro 3D skenování. Fotogrammetrie jako i jiné techniky vyžaduje jisté specifické podmínky, které mimo jiné vychází z parametrů popsaných v první fázi při výběru a řazení předmětů. Platí taktéž pravidlo, že tuto fázi je v př́ípravě digitalizačního projektu nutné dobře promyslet a nepodcenit. Efektivní plánování scény/ateliéru a jeho případných změn s ohledem na jednotlivé skupiny předmětů, nám dokáže ušetřit 
mnoho času a návazných finančních prostředků. Zároveň je to nutné i s ohledem na ochranu samotných předmětů a techniky. Pro vytvoření scény/ateliéru na jakémkoliv místě (interiéru) je nutné brát zřetel na následující kroky.

- Vyklizení prostoru do míry potřebné k samotnému 3D skenování a bezpečné a komfortní manipulaci s exponáty před, během a po snímání a $\mathrm{k}$ prrípravě exponátů čekajících na snímání.

- Prostředí (prostor/místnost), kde se realizuje snímání, má kvůli reflektanci (odrazivosti materiálů) vliv na barevnou věrnost výsledného $3 \mathrm{D}$ modelu. Proto je mnohdy nutné v prostoru, kde skenujeme, zakrýt (matným černým velkoformátovým textilem) okolní nábytek, podlahu (pokud je jakékoliv výraznější barvy) nebo dokonce zdi, pokud mají jinou než bílou/neutrální barvu (např. žluté, krémové, béžové omítky apod.), reflexní plochy (vitríny, skřrině, zasklení, zrcadla na zdech apod.). $V$ prípadě menších objektů je možné použít světelný stan $\mathrm{s}$ točnou umístěnou uvnitř. Tím se nám potenciální ruchy místnosti eliminují.

- Instalace točen a $360^{\circ}$ skenovacích boxů.

- Instalace světelného parku (doporučené značky např. Broncolor, Elinchrom, Fomei, Godox, Hensel, ProFoto).

- Instalace kabeláže (elektrické napájení světelného parku, synchronizace blesků, $360^{\circ}$ točny, atd.).

\section{Průběh 3D skenování / digitalizace}

Tato fáze popisuje základní kroky postupu fotogrammetrického snímání pro 3D digitalizaci sbírkových předmětů, tak abychom dosáhli co nejlepšího výsledku. V této fázi je klíčové dodržet a nepodcenit stanované kroky, protože je zaprvé náročná na čas a za druhé výsledný model bude tak kvalitní, jak kvalitní budou vstupní data. Navíc pokud budeme směřovat $\mathrm{k}$ co možná nejlepší kvalitě nasnímaných dat, nemusíme pak již s daným předmětem znovu manipulovat a riskovat jeho potenciální poškození. Dobrá vstupní data jsou pro úspěch digitalizačního projektu klíčová. Z technického hlediska je pro vytvoření sad fotogrammetrických snímků možné použít širokou škálu fotografických systémů. Jednu skupinu tvoří takzvané bez-zrcadlové fotoaparáty s výměnnými objektivy (např. Canon, Fuji, Nikon, Sony) s formáty APS-C a „FullFrame“. Další skupinou jsou zrcadlové fotoaparáty (např. Canon, Nikon, Sony). Nejdražší skupinou jsou středoformátové systémy (např. Fuji, Hasselblad, Leica, Phase One). V posledních dvou letech lze pro nízkonákladové projekty použít mobilní telefony jako kupř́íkladu Apple iPhone 13 Pro, nebo nejvyšší modely na platformě Android OS (např. OnePlus, Motorola, Samsung, Sony). U fotoaparátů doporučujeme jen modely s možností plně manuálního ovládání všech parametrů (zaostřování, expoziční čas uzávěrky, clona, citlivost, vyvážení bílé), s výsledným obrazovým rozlišením minimálně 20MPix (ideálně 30MPix a víc) a u smartfonů minimálně $12 \mathrm{MPix}$, přičemž dnes existují již modely s 48MPix, 64MPix, 108MPix snímači.

- Barevná kalibrace kombinace fotoaparátu a objektivu ve světelných podmínkách, ve kterých bude realizováno snímání fotoaparátem (např́íklad pomocí xRite, Gretag-McBeth, basICColor, apod.).

- Bezpečné umístění skenovaného předmětu na točnu nebo pozici, která minimalizuje plochy, které nebude možné vyfotit (obr. 7).

- Aplikace podpůrných/fixačních nástrojů.

- Závěrečná kontrola stavu předmětu před skenováním již ve světelných podmínkách, ve kterých bude digitalizován.

- Korekce předmětu (odstranění prachu, vlasců, nečistot atp.).

- Umístění terčů a kalibračních nástrojů pro měřítko, škálování a barevné spektrum.

- 3D skenování (fotografování v případu fotogrammetrie, do nativního formátu RAW výrobce fotoaparátu (každý výrobce používá svůj vlastní RAW formát, kupř́kladu Canon EOS formáty .CR, .CR2, .CR3, Nikon .NEF, někteří výrobci pak unifikovaný formát.DNG). 


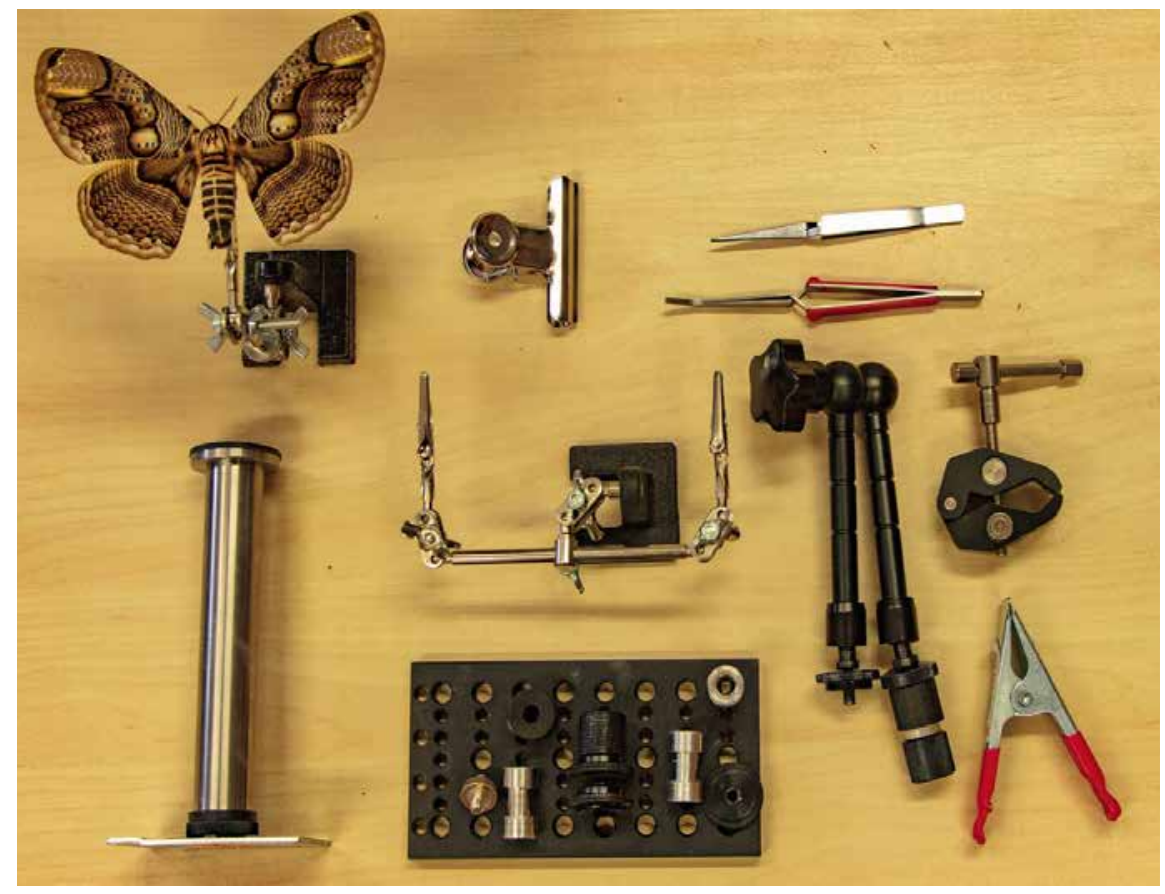

Obr. č. 7. - Ukázka fixační techniky pro focení menších objektu
- Bezpečný přesun předmětu do zóny ,,již zpracovaných/naskenovaných objektů", kde čeká na tým, který má za úkol bezpečný transport předmětu zpátky do depozitáře/restaurátorské dílny/ expozice.

- Odstranění opakovatelně použitelných nástavců/př́ípravků $\mathrm{k}$ fixaci objektu do polohy během skenování, z místa skenování do prostoru určeného pro uskladnění nástrojů mezi skenováním.

- Př́́prava skenovacího místa/točny pro další objekt.

\section{Post-produkce "fotografická"}

V této fázi probíhá první část post-produkce po samotném nasnímání sbírkového předmětu. Vytvořený set fotografií je nutné upravit tak, aby jej bylo možné využít $\mathrm{v}$ další fázi při tvorbě samotného 3D modelu. Z praktického hlediska lze tuto fázi provést paralelně či bezprostředně př́mo $\mathrm{v}$ ateliéru či jeho blízkosti po nasnímání objektu/ů. Důvodem je kontrola výstupů pro př́ípadnou nutnost opětovného nasnímání. Často ale probíhá po samotném dokončení skenování $\mathrm{v}$ rámci výstupů jednoho dne. Kromě dodržení samotného postupu popsaného $\mathrm{v}$ následujících krocích je důležité zejména zálohovat surová vstupní data, které jsme se snažili pořídit, pokud možno v co nejlepší kvalitě. Při dodržení správného postupu v předchozí fázi se s těmito daty dá v budoucnu opakovaně pracovat bez nutnosti opětovné manipulace a skenování sbírkového předmětu.

- Uložení záznamu RAW dat z pamětových karet fotoaparátu na "trvalá“ datová úložiště.

- Import zhotovených fotografických snímků do programového prostředí pro

\section{PROCESSING PHOTOS}

TOOL: ADOBE BRIDGE + CAMERA RAW

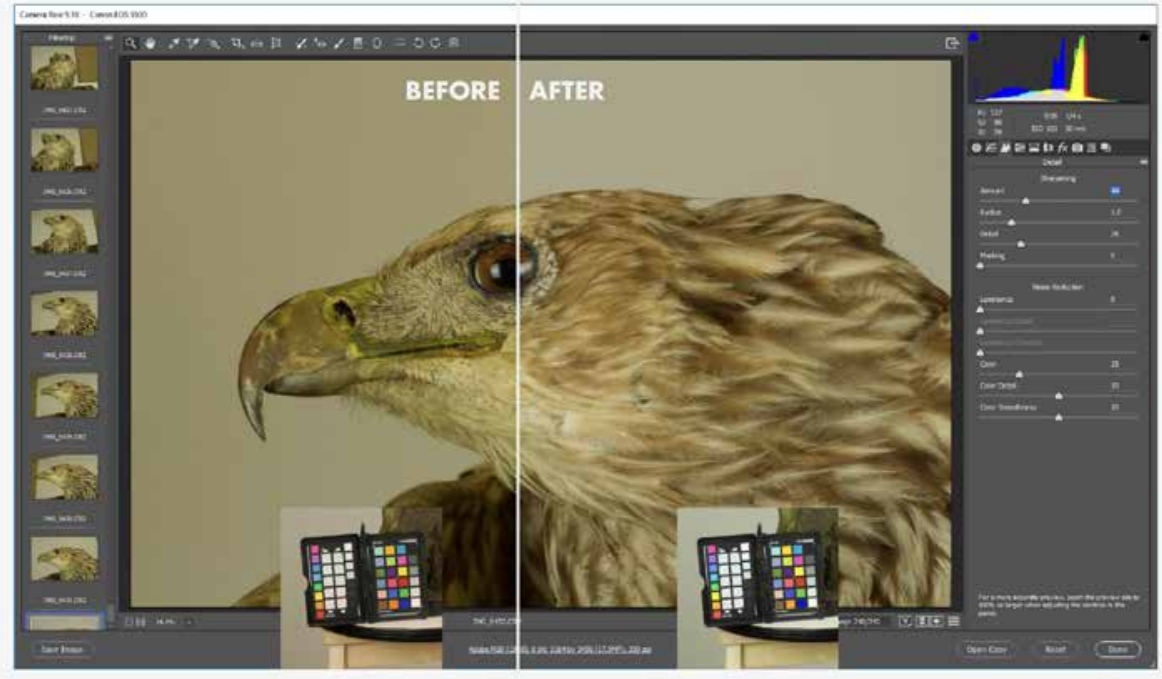

Obr. č. 8 - Fotografická postprodukce snímků v prostředí SW Adobe Camera RAW. 
zpracování RAW (Adobe Photoshop Lightroom Classic CC, Phase One Capture One Pro, apd.)

- Zálohování dat č. 1 = vytvoření „prvních" kopií importovaných fotografií.

- Aplikace základní sady popisných metadat a "klíčových slov“ objektu.

- Aplikace poznávacích unikátních označení dle evidenčního systému muzea na všechny importované záběry předmětu.

- Aplikace šablon nastavení a profilů korekcí expozice, vyvážení bílé, barevných profilů, profilů korekcí optických vlastností užitého objektivu/ů.

- Případná další úprava/korekce expozice/tonality.

- Kontrola správnosti barevné kalibrace $\mathrm{v}$ softwaru pro zpracování RAW snímků před finálním exportem do obrazových nekomprimovaných formátů (např́iklad .TIFF) pro následný import do fotogrammetrického softwaru (například Agisoft Metashape, RealityCapture, Pix4D, 3DF Zephyr) (obr. 8).

- Případná aplikace technických korekcí jako odstraňování digitálního „šumu“ vytvořeného digitálním fotoaparátem.

- Kontrola správnosti přiřazení označení a metadat.

- Export RAW snímků do formátu (.TIFF) pro fotogrammetrický software na datové úložiště přístupné pro tým „3D post-produkce“.

- Záloha č. 2 .TIFF souborů (nižší priorita než zálohování originálních RAW souborů).

- Záloha katalogu Adobe Photoshop Lightroom Classic CC (vysoká priorita).

\section{Post-produkce ,3D“}

V druhé postprodukční fázi jsou zahrnuty pracovní úkony specifické pro tvorbu 3D skenů sbírkových předmětů vyhotovených fotogrammetrickou metodou směřující $\mathrm{k}$ výslednému 3D modelu každého nasnímaného sbírkového předmětu. V této fázi je optimální dodržet postup až do exportu finálních 3D modelů ve formátu .glTF. Často se stává, že je proces ukončen $\mathrm{u}$ exportu objektů do formátu

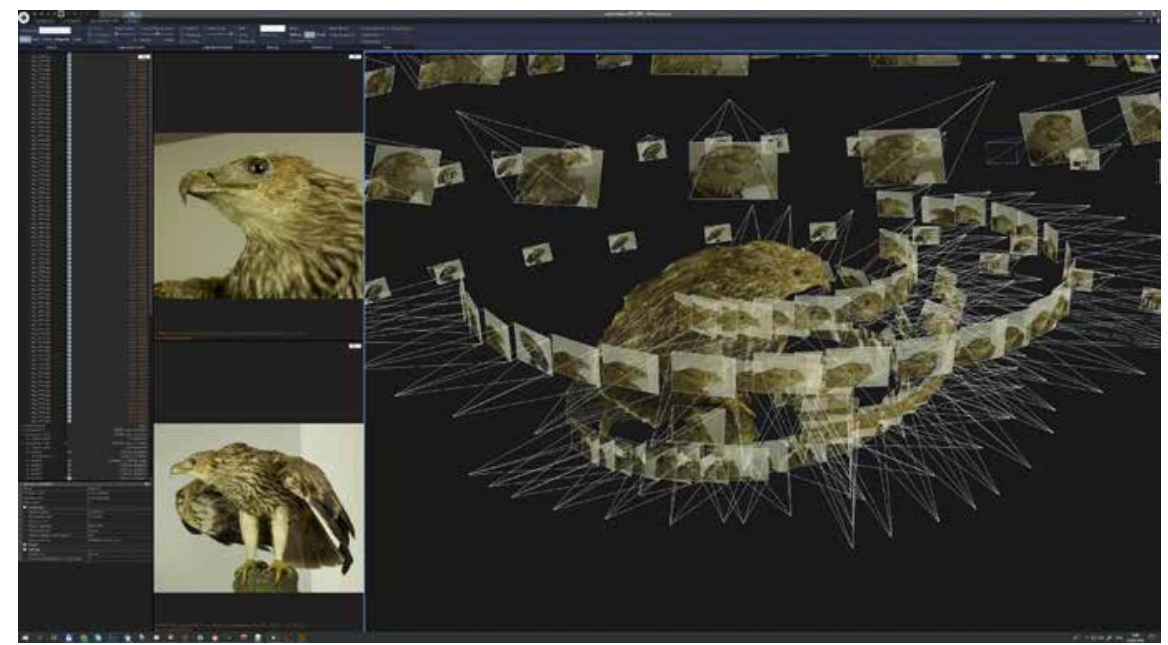

.OBJ, ale $\mathrm{v}$ tomto případě se stále jedná o polotovar, a nikoliv finální model v prezentační kvalitě. Finální model při dodržení zmíněných kroků má dále široký potenciál využití zmíněný v předchozích kapitolách.

- Import kompletní sady fotogrammetrických záběrů/snímků jednoho objektu/sbírkového předmětu (například do Agisoft Metashape, RealityCapture, Pix4D, 3DF Zephyr).

- Alignace $=$ výpočet pozic fotoaparátu u každého z jednotlivých snímků a jejich vzájemných vztahů (obr. 9).

- Výpočet hustého mračna bodů.

- Aplikace kontrolních bodů a re-alignace (pokud nutno).

- Výpočet kontrolní meshe (geometrie povrchu předmětu) s nízkým rozlišením.

- Výpočet meshe (geometrie povrchu předmětu) s vysokým rozlišením.

- Zarovnání a škálování hlavního modelu (obr. 10).

- Výpočet zjednodušeného/simplifikovaného odvozeného modelu (remeshing, parametrizace apod.) (obr. 11).

- Výpočet UV-Map pro tvorbu textur.

- Výpočet barevných fotorealistických textur.

- Export 3D modelů do formátu .OBJ a následná kontrola exportovaných dat.

- Retopologie a simplifikace pro různé výstupní formáty a formy užití/ prezentace.

- Korekce případných geometrických vad (např. Adobe Substance 3D Modeler, Autodesk 3ds MAX, Autodesk MeshMixer, Autodesk MudBox, Blender, apod.)

- Korekce „normál“ povrchové sítě.

- Úprava UV-Map textur (pokud nutno).
Obr. č. 9 - Ukázka alignace za použití programu Reality Capture. 


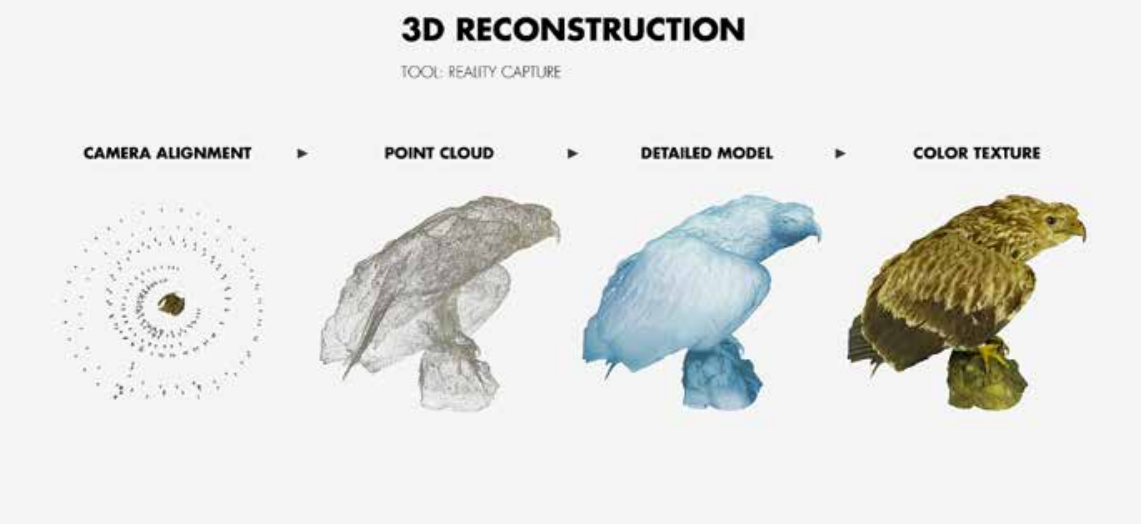

Obr. č. 10 - Ukázka procesu tvorby modelu v programu Reality Capture.

49 Dostupné $z$ : https://www. blender.org/.

50 Dostupné z: https://www. capturingreality.com/.
- Reprojekce textur.

- Manuální korekce vytvořených finálních texturovacích bitmap (pokud nutno). (např. Adobe Substance 3D Painter a Designer, Adobe Photoshop, apod.)

- Mapy metalických vlastností, drsnosti povrchu, bump, apod. (obr. 12)

- Export finálních 3D modeli̊ (.glTF). Jak ekonomicky plánovat 3D digita-
lizaci metodou fotogrammetrie

Celková (nejen) finanční náročnost/nákladnost 3D digitalizačního projektu je přímo závislá na několika základních faktorech. Jedním je samozřejmě zvolené množství sbírkových předmětů vybraných k digitalizaci a jejich komplexnost, povrch a velikost. Dalším faktorem je požadovaná kvalita a parametry jako jsou geometrická přesnost a rozlišení, vizuální rozlišení textur, případné efekty apd. na výsledném 3D modelu objektu. Požadovanou kvalitu nám obvykle určuje potenciální plán využití výsledných modelů. Podle toho, jakých parametrů a kvality chceme dosáhnout, volíme i patřičnou metodu a technologické vybavení potřebné $\mathrm{k}$ realizaci 3D digitalizace.

Důležitým faktorem je také časový harmonogram digitalizačního projektu. Např́klad kolik je času na samotnou digitalizaci sbírkového předmětu s ohledem na jeho využití ve výstavě, expozici či výzkumu. Případně dočasná možnost využití prostor pro digitalizaci, tedy vytvoření dočasného ateliéru například přímo v expozici, depozitáři apd. Tyto faktory se promítnou do nutnosti zajištění například dvou paralelních týmu pro digitalizaci či nákupu výkonnější techniky pro urychlení digitalizace. Podobné parametry jsou pak v druhé fázi 3D post-processingu, kde

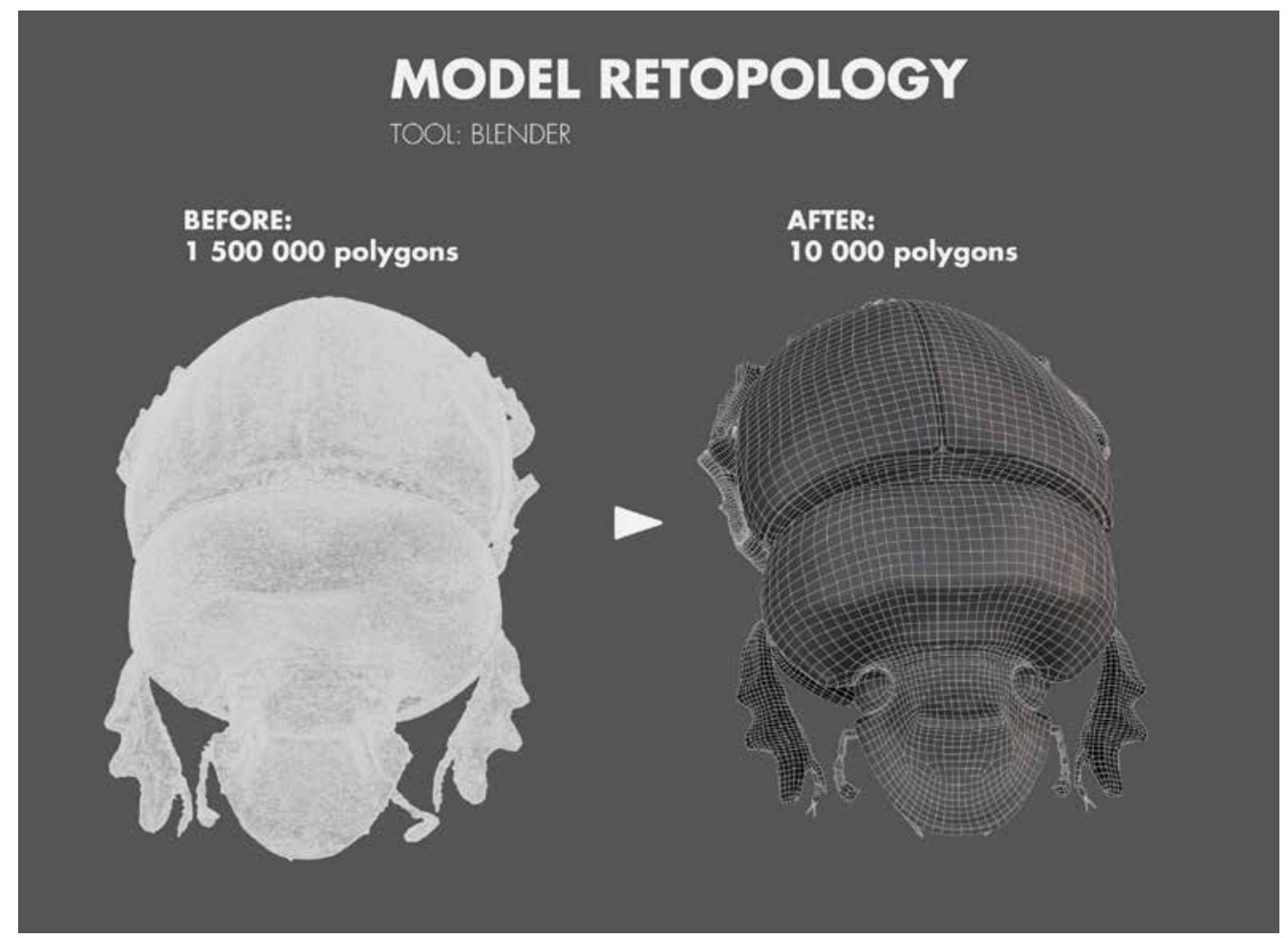

Obr. č. 11 - Ukázka procesu retopologie modelu za použití programu Blender. 
THE MAGIC OF ACCURATE MATERIALS

se hledí na termín do kdy je nutné mít 3D modely předmětů $\mathrm{k}$ dispozici např́iklad pro jejich další využití. To má vliv opět na množství zapojených lidí, případně techniky.

Pro vytvoření odpovídajícího rozpočtu je tedy nutné propojit a definovat všechny výše zmíněné faktory. Zároveň optimalizací jednotlivých faktorů lze dokázat požadovaný rozpočet poměrně efektivně snížit nebo získat více kvalitního obsahu. Velké investice do technického vybavení samy o sobě bez adekvátního odborného/ technického know-how nezaručují požadovaný výsledek. Oproti tomu levnějším vybavením, ale s kvalitní metodikou a pečlivou a systematickou prací je možné dosáhnout v praxi velmi dobrých výsledků. 3D skenování fotogrammetrickými metodami je dnes již možné realizovat $\mathrm{v}$ adekvátní kvalitě i za použití rádově levnějších / cenově příznivějších nejnovějších modelů smartphonů nebo fotoaparátů střední třídy (s výměnnými objektivy jako jsou zrcadlovky a "bez-zrcadlovky“). Pro 3D výsledné modely v absolutní fotorealistické vizuální kvalitě již dnes není nutné pořizovat nejdražší objektivy, středoformátové digitální zrcadlovky nebo zábleskový světelný park.

Existuje již také kvalitní bezplatný software (např. Blender ${ }^{49}$ ), čímž odpadají některé počáteční softwarové náklady, které byly donedávna nutné. Případně další softwary přichází s obchodními modely přístupnými i běžným uživatelưm či kulturním a vzdělávacím institucím (např. RealityCapture $^{50}$ ). V současnosti je již možné začít 3D skenovat / digitalizovat $\mathrm{s}$ řádově menším rozpočtem. Vše se odvíjí zejména od nároků na kvalitu výsledných 3D modelů/digitalizátů a zamýšleného způsobu/ů jejich dalšího použití. A v neposlední řadě také na dostupném týmu lidí v instituci či rozvíjející se mezioborové spolupráci. Zde je myšlena i potenciální spolupráce s kreativními průmysly, kdy se instituce nestává jen zadavatelem či poskytovatelem obsahu, ale partnerem a samotným uživatelem.

Primárně by instituci mělo jít o dosažení nejlepší kvality jak dat ze skenování (první

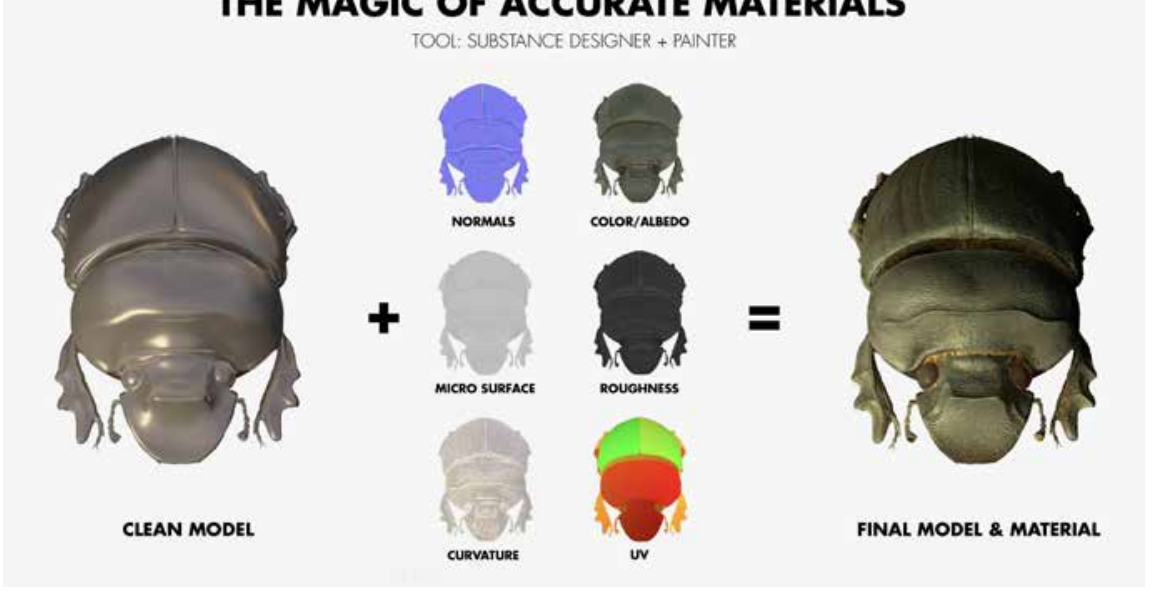

fáze), tak výsledných modelů a formátů (2 fáze), pro zajištění jejich nejširšího pole možnosti využití od vědy a výzkumu až po kreativní průmysly. I v takovém případě lze z ekonomického hlediska digitalizační projekt efektivně optimalizovat. Zde je velmi důležité rozdělení dvou fází pracovního procesu - samotná digitalizace a 3D post-processing. Klíčem $\mathrm{k}$ úspěchu je kombinace vlastních investic do vybavení, odborného personálu a následně služeb. Budeme-li se řídit postupem z kapitoly „Fotogrammetrie a optimální postup", tak v podstatě kroky 1-4 lze kompletně zajistit na úrovni instituce, částečně i některé body z kroku 5. To znamená v případě vlastní investice do techniky pro 3D digitalizaci/skenování a zároveň vyškolení personálu není nutné tuto činnost řešit formou služeb. Samozřejmě zde je důležitá kvalita pořízených vstupních dat, tedy i samotné techniky, pro dosažení nejlepších a nejpřesnějších výsledků v další fázi postprodukce. Čas profesionálního studia za samotnou 3D digitalizaci je velmi drahý, takhle by nemusel být investován do části pracovního procesu, který by si dokázala instituce zařídit sama. To ovšem neplatí pro druhou fázi 3D post-processingu, kde je důležitý profesionální přístup, který si již sama instituce dokáže svépomocí zajistit mnohem obtížněji. Navíc je zde zbytečné platit za velmi drahé licence pro profesionální software. Jinými slovy takto lze efektivně rozdělit náklady na digitalizační projekt. Investice do vybavení a personálu v první fázi má navíc v instituci širší využití, nejen pro 3D digitalizaci. Vybudovaný stálý, dočasný či přenosný fotografický ateliér či mobiliář své uplatnění najde i při dokumentační digitalizaci, navíc jej instituce již
Obr. č. 12 - Ukázka procesu tvorby finálních texturovacích bitmap a materiálů za pomocí programú Adobe substance $3 D$ designer a painter. 
často mají. To samé je již v př́ípadě vyškoleného fotografa, či spolupráce s takovým fotografem, kterou lze samožrejmě také řešit formou služby. Profesionálního grafika pro 3D modelování se zkušenostmi a profesionálním softwarem je na druhou stranu již určitě lepší řešit formou služby a maximálně efektivně využit jeho čas, právě pro 3D post-processing.

$V$ př́ipadě, že je celý $3 \mathrm{D}$ digitalizační projekt financován formou služby/dodavatelem např́íklad $z$ účelových prostředků, což je velmi častý př́ípad, je pak zcela zásadní správná definice samotného projektu s ohledem na faktory a postupy zmíněné výše. S ohledem na požadovanou kvalitu je důležité, aby se projekt nezastavil v pátém kroku postupu u „Export 3D modelů do formátu .OBJ“", což je bohužel častý př́pad. 3D model sice na první pohled vypadá dobře, nicméně má omezené využití bez další postprodukce např́klad materiálu, korekcí modelu, světla apd. Tato postprodukce je klíčová pro využití např́klad v některých oblastech kreativního průmyslu či oblasti, kde je nutná vysoká geometrická přesnost a věrnost modelu. Autorské právo a problematika digitálních kopií

3D skenování metodou fotogrammetrie umožňuje relativně snadné pořízení digitální kopie sbírkového předmětu, a tím i jeho publikaci a další šíření. Samotným skenováním vzniká autorské právo vyhotoviteli digitální kopie, protože je zpravidla nutné takovou digitální kopii před použitím dále autorsky zpracovat. V př́padě, že digitální kopii vyhotovuje zaměstnanec muzea, pak se jedná o klasické zaměstnanecké dílo. $V$ takovém případě jsou osobnostní práva zaměstnance nedotčena - muzeum musí uvádět jeho autorství, nicméně majetková práva náleží muzeu, např. zisk $\mathrm{z}$ prodeje 3D tisků $\mathrm{v}$ obchodě muzea.

Složitější situace může nastat, když skenování a následnou úpravu dat provádí externí subjekt. Je v zájmu muzea, aby výměnou za bezplatný př́stup $\mathrm{k}$ dílům zároveň vyžadovala autorskou smlouvu, která bude chránit veřejný zájem. Veřejným zájmem je v tomto případě, aby co nejširší veřejnost měla $\mathrm{k}$ získaným datům př́stup, at' už se jedná o odbornou nebo laickou veřejnost. Jedním $\mathrm{z}$ cílů muzea je zpřístupňovat kulturní dědictví a zachovat jej pro př́ístí generace. Proto je vhodné smluvně ošetřit, aby nabyvatel digitálních kopií zajistil možnost př́stupu $\mathrm{k}$ těmto datům prostřednictvím vhodné licenční smlou$v^{51}$. Nabízí se zde využít jako vzor open source licence či specifických a zároveň srozumitelných licencí využití naprríklad MIT $^{52}$ nebo Creative Commons ${ }^{53}$. Český autorský zákon tyto typy smluv sice př́imo neuvádí, ale nic nebrání sepsání běžné autorské smlouvy v duchu znění MIT či CC. V praktické rovině se pak nabyvatel může zavázat ke zveřejnění zdrojových dat na volně dostupných platformách jako je Sketchfab a jednu kopii také přenechat muzeu s licencí, jež muzeum opravňuje dále kopii šírit třetím stranám.

Zvolením správné licenční smlouvy u zpř́istupněného obsahu je možné se vyhnout problémům při generování zisku $\mathrm{z}$ digitálních kopií, ale také $\mathrm{v}$ možnostech jeho dalšího využití. Je vhodné komunikovat tyto podmínky i veřejně - např. na webu muzea.

\section{Závěr}

Je pravděpodobné, že se $3 \mathrm{D}$ digitalizace muzejních sbírkových předmětů nestane masovým způsobem digitalizace kulturního dědictví vedle klasických 2D postupů a zejména digitalizace dat. Nicméně zejména díky rozvoji a dostupnosti technologií a nástrojů, vysokému potenciálu využití a nárůstu poptávky po 3D obsahu jak ze strany uživatelů, tak různých odvětví včetně kreativních průmyslů a edukace, lze 3D digitalizaci v muzeích již zařadit do standartních procesů digitalizace sbírek. Zároveň se ukazuje, že 3D digitalizace sbírek má potenciál zpřístupnit kulturního dědictví novou formou s novou přidanou hodnotou zejména pro současné mladé a nové generace návštěvníků. Při srovnání dostupných metod 3D digitalizace s ohledem na jejich technologický rozvoj a dostupnost, ekonomickou náročnost, možné obchodní modely 
a kvalitu výstupů, vychází nám nejlépe metoda fotogrammetrie. $\mathrm{Z}$ toho důvodu se studie zaměřila právě na tuto metodu 3D digitalizace a její aktuální přiblížení kulturním institucím. Předložený detailní pracovní poustup digitalizačního projektu využívající fotogrammetrii od $\mathrm{A}$ do $\mathrm{Z}$ vychází z dlouholeté praxe a zkušeností specialistů z kulturního i soukromého sektoru a aktuální literatury. Studie tak může být použita jako návod pro kulturní instituce, které se pro 3D digitalizaci rozhodují.

\section{Poděkování:}

Kromě autorského týmu se na př́pravě studie podíleli další spolupracovníci zejména formou konzultací z oblasti kulturního, akademického a soukromého sektoru. Proto bychom rádi poděkovali Benu Markelovi, Karolíně Hulanské, Františku Sionovi, Adamu Cironisovi, Adamu Pospíšilovi, Martinu Svědínkovi, Jakubu Antošovi, Josefu Součkovi, Kateřině Zwyrtkové, Jakubu Ročkovi a Karolína Hnětkovské. Předložená práce vznikla za finanční podpory Ministerstva kultury $\mathrm{v}$ rámci institucionálního financování dlouhodobého koncepčního rozvoje výzkumné organizace Národní muzeum (DKRVO 2019-2023/26.III.a, 00023272) a částečně se podporou Technologické agentury ČR v rámci programu ÉTA-TL05000298.

\section{Seznam literatury}

APOLLONIO, Fabrizio, et al, A Photogrammetry-Based Workflow for the Accurate $3 D$ Construction and Visualization of Museums Assets, Remote Sensing, 2021, vol 13, no. 3: 486. https://doi.org/10.3390/ rs13030486

AYSHA, M. 3D Builder, free 3D modeling software by Microsoft. 3Dnatives [online], August 31, 2020 [cit. 15. 11. 2021]. Dostupnéz: https://www.3dnatives.com/ en/ 3d-builder-microsoft-310820206/\#!

BARRATT, R. P., Speculating the Past: 3D Reconstruction in Archaeology. In: Champion, E. M. (Ed.), Virtual Heritage: A Guide, 2021. London: Ubiquity Press, pp. 13-23.
BENTKOWSKA-KAFEL, and LINDSAY, MacDonald. Digital Techniques for Documenting and Preserving Cultural Heritage. New edition ed., Arc Humanities Press, 2018. 369 p. muse.jhu.edu/ book/80843.

CRONIN, Charles. Possession Is 99\% of the Law: 3D Printing, Public Domain Cultural Artifacts and Copyright. Minnesota Journal of Law, Science and Technology, 2016, vol. 17, iss. 2, pp. 709-736. (https:// scholarship.law.umn.edu/mjlst/vol17/ iss $2 / 3 /$ )

DEBAILLEUX, Laurent, GEOFFREY, Hismans, DUROISIN, Natacha. Exploring Cultural Heritage Using Virtual Reality. In: M. Ioannides (Ed.), Digital Cultural Heritage. Lecture Notes in Computer Science, Februar 2018, pp. 1-16. EBRAHIM, Mostafa, Abdel-Bary, 3D Laser Scanner's Techniques Overview. International Journal of Science and Research, October 2015, vol. 4, no. 10, pp. 323-331.

GIAKALARAS, Marios M. 3D Technologies for Cultural Heritage. Gaming Engines, September 24, 2020, pp. 1-10.

GIMENO, Jesús, et al. Combining traditional and indirect augmented reality for indoor crowded environments. A case study on the Casa Batlló museum. Computer \& Graphics, 2017, vol. 69, pp. 92-103.

GRUEN, Armin, Everything moves: The rapid changes in photogrammetry and remote sensing, Geo-spatial Information Science, 2021, vol. 24:1, pp. 33-49, DOI: 10.1080/10095020.2020.1868275

CHAMPION, Erik, Virtual Heritage. London: Ubiquity Press, 2021, p. 153. DOI: https://doi.org/10.5334/bck

LINGUA, Andrea, PIUMATTI, Paolo, RINAUDO, Fulvio, Digital photogrammetry: a standard approach to cultural heritage survey. The International Archives of the Photogrammetry, Remote Sensing and Spatial Information Sciences, 2003, Vol. 14, Part 5/W12, pp. 210-215

MEDINA, Joshua J., et al, A rapid and cost-effective pipeline for digitization of museum specimens with $3 D$ photogrammetry. 
PLOS ONE, 2020, vol. 15(8), pp. 1-14: e0236417. https://doi.org/10.1371/journal.pone. 0236417

MONTUSIEWICZ, Jerzy, et al, Structuredlight $3 D$ scanning of exhibited historical clothing - a first-ever methodical trial and its results. Heritage Science, 2021, vol. 9, no. 74, pp. 1-20. https://doi.org/10.1186/ s40494-021-00544-x

RAHAMAN, Hafizur and CHAMPION, Erik, To 3D or Not 3D: Choosing a Photogrammetry Workflow for Cultural Heritage Groups, Heritage, 2019, vol. 2, no. 3, pp. 1835-1851. (https://espace.curtin.edu. au/handle/20.500.11937/75936)

RAHAMAN, Hafizur, CHAMPION, Erik, BEKELE, Mafkereseb. From photo to 3D to mixed reality: A complete workflow for cultural heritage visualisation and experience. Digital Applications in Archaeology and Cultural Heritage, 2019, vol. 13.

REA, Naomi. Can "Assassin's Creed" Help Rebuild Notre Dame? How Restoring the Cathedral will Rely on Both New Tech and Ancient Knowhow. Artnet [online], April 18, 2019 [cit. 15. 11. 2021]. Dostupné z: https://news. artnet.com/market/how-technologies-old-and-new-will-be-needed-to-rebuild-notre-dame-1520689.

RELJIĆ, I. \& DUNDER, Ivan, Application of photogrammetry in 3D scanning of physical objects. TEM Journal, 2019, vol. 8, pp. 94-101. https://doi. org/10.18421/TEM81-13.

SHENG, W., et al. Photorealistic VR space reproductions of historical kyoto sites based on a next-generation 3D game engine. 日本シミュレーション学会英 文誌, 2015, vol. 1, no.1, pp. 188-204.

SCHÖNBERGER, Johannes L., FRAHM, Jan-Michael, Structure-from-Motion
Revisited, 2016 IEEE Conference on Computer Vision and Pattern Recognition (CVPR), 2016, pp. 4104-4113, doi: https://doi.org/10.1109/CVPR.2016.445.

SKARLATOS, D., KIPARISSI, S., Comparison of laser scanning, photogrammetry and SFM-MVS pipeline applied in structures and artificial surfaces, ISPRS Ann. Photogramm. Remote Sens. Spatial Inf. Sci, 2012, I-3, pp. 299-304.

SMITH, Matthew, et al. Using 3D modelling and game engine technologies for interactive exploration of cultural heritage: An evaluation of four game engines in relation to roman archaeological heritage. Digital Applications in Archaeology and Cultural Heritage, September 14, 2019.

WOOD, John, et al, Structure from motion photogrammetry endhances paleontological resource documentation, research, preservation and education efforts for national park service areas. In book: Fossil Record 7, Publisher: New Mexico Museum of Natural History and Science, 2021, pp. 513-524

YOSRA, K. The Manacor Museum 3D printed replicas so that visitors can touch its exhibits. 3D Adept Media [online], July 6, 2018, [cit. 15. 11. 2021]. Dostupné z: https://3dadept.com/the-manacor-museum-3d-printed-replicas-so-that-visitors-can-touch-its-exhibits/)

ZUZA, Mikolas, Fotogrammetrie - 3D skenování s použitím fotoaparátu či mobilu, [online], [cit. 15. 11. 2021]. Dostupné z https://josefprusa.cz/fotogrammetrie-3d-skenovani-s-pouzitim-fotoaparatu-ci-mobilu/ 